\title{
Nathalie Catellani-Dufrêne, "L'adieu aux Muses»: Joachim Du Bellay, traducteur de George Buchanan
}

\section{Filippo Fassina}

\section{(2) OpenEdition}

1 Journals

\section{Edizione digitale}

URL: http://journals.openedition.org/studifrancesi/9167

DOI: ERREUR PDO dans /localdata/www-bin/Core/Core/Db/Db.class.php L.34 : SQLSTATE[HYO00]

[2006] MySQL server has gone away

ISSN: 2421-5856

\section{Editore}

Rosenberg \& Sellier

\section{Edizione cartacea}

Data di pubblicazione: 1 juin 2008

Paginazione: 176

ISSN: 0039-2944

\section{Notizia bibliografica digitale}

Filippo Fassina, «Nathalie Catellani-Dufrêne, «L'adieu aux Muses»: Joachim Du Bellay, traducteur de George Buchanan», Studi Francesi [Online], 154 (LII | I) | 2008, online dal 30 novembre 2015, consultato il 07 janvier 2021. URL: http://journals.openedition.org/studifrancesi/9167 ; DOI: https://doi.org/ 10.4000/studifrancesi.9167

Questo documento è stato generato automaticamente il 7 janvier 2021.

\section{(c) (i) (9)}

Studi Francesi è distribuita con Licenza Creative Commons Attribuzione - Non commerciale - Non opere derivate 4.0 Internazionale. 


\title{
Nathalie Catellani-Dufrêne, «L'adieu aux Muses»: Joachim Du Bellay, traducteur de George Buchanan
}

\author{
Filippo Fassina
}

\section{NOTIZIA}

NATHALIE CATELLANI-DUFRÊNE, «L'adieu aux Muses»: Joachim Du Bellay, traducteur de George Buchanan, «Bibliothèque d'Humanisme et Renaissance», LXIX, 2 (2007), pp. 425-433.

1 L'A. offre un quadro dettagliato e ricco di esempi del rapporto di amicizia e di citazione letteraria tra Joachim Du Bellay e George Buchanan. I punti comuni ai due autori sono numerosi sia a livello tematico, sia a livello lessicale e stilistico. In particolare, Du Bellay tradusse due opere dell'amico: un'ode del 1553 sul siège di Metz e un Adieu aux Muses del 1552 , su cui si concentra il presente contributo. Dopo averne brevemente riassunto il contenuto, l'A. analizza il metodo di imitatio messo in opera da Du Bellay, sottolineando soprattutto la ripresa dei topoi comuni e il rispetto - che spesso sfiora il calco - delle figure retoriche. Così come vengono elencati i punti di contatto parimenti vengono descritte le divergenze legate, in particolar modo, ai giochi di parole introdotti da Du Bellay. Dal punto di vista tematico, notevole è il passaggio da un addio alle Muse vero e proprio in Buchanan a un'invocazione delle Ninfe, a indicare la ricerca di una poesia più naturale che, pur basandosi su modelli, dimostra l'emergere di un genio poetico autonomo. 